\title{
Assessment of Postpartum Hemorrhage in a University Hospital in Eastern Ethiopia: A Cross-Sectional Study
}

\author{
Sinetibeb Mesfin' \\ Merga Dheresa (D) \\ Sagni Girma Fage (iD) \\ Abera Kenay Tura iD ${ }^{1,2}$ \\ 'School of Nursing and Midwifery, \\ College of Health and Medical Sciences, \\ Haramaya University, Harar, Ethiopia; \\ ${ }^{2}$ Department of Obstetrics and \\ Gynaecology, University Medical Centre \\ Groningen, University of Groningen, \\ Groningen, the Netherlands
}

\begin{abstract}
Objective: Despite implementation of different strategies, postpartum hemorrhage ( $\mathrm{PPH})$ continued to account for a substantial proportion of maternal deaths in Ethiopia. The objective of this study was to assess the magnitude of PPH and its associated factors among women who gave birth in a university hospital in eastern Ethiopia from 1 to 31 March 2020.
\end{abstract}

Methods: An institution-based cross-sectional study was conducted. A review of 653 randomly selected medical records of all deliveries from 1 March 2018 to 29 February 2020 in Hiwot Fana Specialized University Hospital (HFSUH), a university hospital in eastern Ethiopia, was conducted. Data were collected on sociodemographic characteristics, obstetric and reproductive health conditions, and presence of PPH. Data were coded, checked for completeness and entered using EpiData 3.1 and exported to SPSS 20 for analysis. Results were expressed using frequencies, tables and figures. Binary and multiple logistic regression were fitted to identify factors associated with PPH and associations were described using adjusted odds ratio (aOR) along with 95\% confidence intervals (CI). Associations with $\mathrm{p}<0.05$ in the multivariable logistic regression were declared as statistically significant.

Results: From a total of $642(98.3 \%)$ women included in this study, $83(12.9 \%$; $95 \% \mathrm{CI}$ 10.4-15.6) had PPH. Maternal age $>35$ years ( $\mathrm{aOR}=3.08$; 95\% CI 1.56, 6.07), no antenatal care $(\mathrm{aOR}=3.65 ; 95 \% \mathrm{CI} 1.97,6.76)$, history of $\mathrm{PPH}(\mathrm{aOR}=4.18 ; 95 \% \mathrm{CI} 1.99,8.82)$, and being grand multigravida ( $\mathrm{aOR}=3.33 ; 95 \% \mathrm{CI} 1.14,9.74)$ were significantly associated with having PPH.

Conclusion: A high proportion of women who gave birth in HFSUH experienced PPH. Prevention and management of PPH should focus on improving antenatal care and prioritize grand multigravida, older women, and women with a previous history of PPH.

Keywords: magnitude, morbidity, mortality, postpartum hemorrhage, $\mathrm{PPH}$

\section{Introduction}

Postpartum hemorrhage (PPH), defined as blood loss over $500 \mathrm{~mL}$ after vaginal delivery or more than $1000 \mathrm{~mL}$ after a cesarean section, is a major cause of maternal morbidity and mortality. ${ }^{1}$ It is estimated that every 10 minute a woman dies of PPH, contributing to the majority of deaths from obstetric hemorrhage. ${ }^{2,3}$ Although deaths from PPH may occur outside health care facilities as a result of high home deliveries, a significant number occur in hospitals, where effective emergency care has the potential to save lives. ${ }^{4}$ In Africa, where maternal mortality is exponentially higher than other regions, $\mathrm{PPH}$ has an even more profound role. ${ }^{5,6}$
Correspondence: Abera Kenay Tura School of Nursing and Midwifery, College of Health and Medical Sciences, Haramaya University, P.O.B. 235, Harar, Ethiopia Email a.k.tura@haramaya.edu.et 
From 2013 to $2018,41-51 \%$ of all maternal deaths in Ethiopia were attributed to hemorrhage, mainly $\mathrm{PPH}^{7}{ }^{7}$ In addition to the high maternal mortality from $\mathrm{PPH}$, thousands of women survive from PPH and continue to suffer from its debilitating consequences. ${ }^{8} \mathrm{PPH}$ is associated with long- and short-term health problems: chronic illness, disability, increased risk of death and/or poor growth and development of child, and vital organ failure. ${ }^{9}$ Focusing on the number of deaths or complications may underestimate the burden of $\mathrm{PPH}$, as majority of non-severe forms remain unreported in majority of databases or studies.

Low resource settings like Ethiopia have high PPH also characterized by high fatality rate. Proportion of PPH in Ethiopia ranges from $5.8-16.6 \%$ based on the study settings, study design or nature of study ${ }^{10-13}$ In a national cross-section study, PPH was found to have the highest case fatality rate among all the direct obstetric complications in Ethiopia. ${ }^{14} \mathrm{PPH}$ is more likely among women with macrosomia, those who had histroy of $\mathrm{PPH}$, previous cesarean, abnormal placentation, prolonged third stage of labor, hypertensive disorders of pregnancy, soft tissue lacerations or induction of labor. ${ }^{15-17}$ Active management of the third stage of labor is the most effective strategy for prevention of PPH. ${ }^{18}$

Given the risk of under reporting among studies because of the focus on deaths or severe forms of morbidity from $\mathrm{PPH},{ }^{19,20}$ studies focusing on the overall morbidity from PPH are essential to reveal the burden of the problem for designing appropriate preventive services and planning for resource allocation. However, there is limited data on burden of PPH, especially among women surviving complications. The objective of this study was to assess magnitude of PPH and its associated factors in Hiwot Fana Specialized University Hospital (HFSUH), eastern Ethiopia.

\section{Methods}

\section{Study Setting and Population}

The study was conducted in HFSUH, a tertiary university hospital in eastern Ethiopia, located in Harar town, $526 \mathrm{~km}$ from Addis Ababa, the capital. HFSUH is the major referral hospital in eastern Ethiopia and is affiliated with the College of Health and Medical Sciences of Haramaya University. A 201 bedded hospital and on transformation to a 1000-bedded hospital during the study period, the hospital serves as a referral hospital $24 / 7$ for more than five million inhabitants in eastern Ethiopia. In addition to giving basic medical care for patients, HFSUH serves as the main referral center of care for specialized medical, obstetric, gynecologic and pediatric illnesses, among others. During the study period, the department of obstetrics and gynaecology was run by four consultants, eight resident obstetricians and gynecologists and 31 nurse (midwives).

An institution based cross-sectional study was conducted from 1-31 March 2020. All women who gave birth in HFSUH constituted the source population. All women who gave birth in the hospital from 1 March 2018 to 29 February 2020 were the study population. The identity of women who gave birth in the hospital was determined from delivery registers, admission and discharge logbooks, and operation theater records. All women admitted in the hospital from 1 March 2018 to 29 February 2020 were included if their cards contain complete information about their obstetric conditions, including PPH-related management. Charts with incomplete information were excluded.

The sample size was calculated by using single proportion formula with $95 \%$ confidence interval (CI), margin of error 3\% and proportion of PPH (16.7\%) from the study conducted in Southern Ethiopia. ${ }^{12}$ After considering a $10 \%$ non-response rate, the final sample size was 653 . Using the women's medical registration numbers (MRNs) during the study period $(\mathrm{n}=8431)$, a sampling frame was prepared and entered to the computer to generate random samples.

\section{Measurement and Statistical Analysis}

Data were collected through review of medical records by five trained BSc midwives using a semi-structured data extraction form developed from different literature..$^{10,11,13}$ Data on sociodemographic characteristics, pregnancy and obstetrics history, current labor- and delivery-related information, and PPH related questions were collected. The questionnaire was pre-tested on 33 deliveries outside the study period before the data collection and the adequacy of the checklist was evaluated and appropriate modifications were made.

Presence of PPH, defined as having a clinical diagnosis of PPH on the medical record or reported excess blood loss as per the WHO $2018,{ }^{1}$ presence of sign and symptoms of hypovolemia, a decline of $10 \%$ or more in the baseline hematocrit level regardless of the route of delivery, ${ }^{21}$ was considered as the dependent variable whereas sociodemographic characteristics, obstetrics-related (post- and ante- 
partum) factors, and labor and delivery-related factors were investigated as independent variables. The collected data were coded, cleaned and entered in to EpiData 3.1 and exported to SPSS 20 for analysis. Descriptive statistics such as simple frequencies, measures of central tendency and measures of dispersion were used. Binary logistic regression was done to identify association between independent variables and PPH and variables with $p-\leq 0.25$ were included in the multivariable analysis after checking for multicollinearity. The Hosmer-Lemeshow test was used to test model fitness. An adjusted odds ratio (aOR) with $95 \%$ CI was used to describe factors associated with PPH and level of statistical significance was declared at $p<0.05$.

\section{Ethical Considerations}

This study was conducted in accordance with the Helsinki Declaration for research involving human subjects. ${ }^{22}$ In addition, ethical clearance was obtained from the Institutional Health Research Ethics Review Committee of College of Health and Medical Sciences, Haramaya University, Ethiopia (ref no: IHRERC 059). Informed consent was obtained from the chief medical officer of the hospital. Data were collected using anonymous forms and no individual identifier information was collected or analyzed. The collected questionnaire was locked and was accessible only to the research team.

\section{Results}

\section{Sociodemographic Conditions}

Of 653 medical records reviewed, 642 (98.3\%) were eligible and included in the analysis: 11 incomplete records were excluded. The mean age of participants was 27.26 $( \pm 5.6)$ years. Majority of the participants were 20 - to 34 years-old $(72.6 \%)$, multigravida $(59.8 \%)$, gave birth vaginally $(86.3 \%)$, received antenatal care $(60.6 \%)$, and urban residents (59.5\%) (Table 1$)$.

A total of 207 (32.2\%) women had developed some complications, pregnancy-induced hypertension $(24.2 \%)$ followed by prolonged labor (17.9\%) (Figure 1).

\section{Magnitude of PPH and its Associated Factors}

A total of $83(12.9 \%$; 95\% CI; 10.4-15.6) of women had PPH. Uterine atony $(49.4 \%)$, retained membrane $(19.3 \%)$
Table I Sociodemographic Characteristics of Women Who Gave Birth in HFSUH, Ethiopia, 2020 ( $n=642$ )

\begin{tabular}{|c|c|c|c|}
\hline Variable & Category & Frequency & $\begin{array}{l}\text { Percentage } \\
\text { (\%) }\end{array}$ \\
\hline Age & $\begin{array}{l}<20 \text { years } \\
20-34 \text { years } \\
\geq 35 \text { years }\end{array}$ & $\begin{array}{l}88 \\
466 \\
88\end{array}$ & $\begin{array}{l}13.7 \\
72.6 \\
13.7\end{array}$ \\
\hline Residence & $\begin{array}{l}\text { Urban } \\
\text { Rural }\end{array}$ & $\begin{array}{l}363 \\
279\end{array}$ & $\begin{array}{l}56.5 \\
43.5\end{array}$ \\
\hline Gravidity & $\begin{array}{l}1 \\
2-4 \\
\geq 5\end{array}$ & $\begin{array}{l}191 \\
295 \\
156\end{array}$ & $\begin{array}{l}29.8 \\
46 \\
24.2\end{array}$ \\
\hline Parity & $\begin{array}{l}1 \\
2-4 \\
\geq 5\end{array}$ & $\begin{array}{l}190 \\
384 \\
68\end{array}$ & $\begin{array}{l}29.6 \\
59.8 \\
10.6\end{array}$ \\
\hline Gestational age & $\begin{array}{l}<37 \text { weeks } \\
37-41 \text { weeks } \\
\geq 42 \text { weeks }\end{array}$ & $\begin{array}{l}37 \\
57 \mid \\
34\end{array}$ & $\begin{array}{l}5.8 \\
88.9 \\
5.3\end{array}$ \\
\hline ANC follow up & $\begin{array}{l}\text { Yes } \\
\text { No }\end{array}$ & $\begin{array}{l}492 \\
150\end{array}$ & $\begin{array}{l}76.6 \\
23.4\end{array}$ \\
\hline History of previous PPH & $\begin{array}{l}\text { Yes } \\
\text { No }\end{array}$ & $\begin{array}{l}51 \\
591\end{array}$ & $\begin{array}{l}7.9 \\
92.1\end{array}$ \\
\hline History of previous CS & $\begin{array}{l}\text { Yes } \\
\text { No }\end{array}$ & $\begin{array}{l}40 \\
602\end{array}$ & $\begin{array}{l}6.2 \\
93.8\end{array}$ \\
\hline Complications & $\begin{array}{l}\text { Yes } \\
\text { No }\end{array}$ & $\begin{array}{l}207 \\
435\end{array}$ & $\begin{array}{l}32.2 \\
67.8\end{array}$ \\
\hline Onset of labor & $\begin{array}{l}\text { Spontaneous } \\
\text { Induced }\end{array}$ & $\begin{array}{l}551 \\
91\end{array}$ & $\begin{array}{l}85.8 \\
14.2\end{array}$ \\
\hline Labor augmented $(n=55 \mathrm{I})$ & $\begin{array}{l}\text { Yes } \\
\text { No }\end{array}$ & $\begin{array}{l}39 \\
512\end{array}$ & $\begin{array}{l}7.1 \\
92.9\end{array}$ \\
\hline Duration of labor & $\begin{array}{l}\geq 24 \text { Hours } \\
<24 \text { hours }\end{array}$ & $\begin{array}{l}37 \\
599\end{array}$ & $\begin{array}{l}5.8 \\
94.2\end{array}$ \\
\hline Obstructed labor & $\begin{array}{l}\text { Yes } \\
\text { No }\end{array}$ & $\begin{array}{l}28 \\
614\end{array}$ & $\begin{array}{l}4.4 \\
95.6\end{array}$ \\
\hline Mode of delivery & $\begin{array}{l}\text { Vaginal } \\
\mathrm{C} / \mathrm{S}\end{array}$ & $\begin{array}{l}554 \\
88\end{array}$ & $\begin{array}{l}86.3 \\
13.7\end{array}$ \\
\hline Episiotomy $(n=554)$ & $\begin{array}{l}\text { Yes } \\
\text { No }\end{array}$ & $\begin{array}{l}82 \\
472\end{array}$ & $\begin{array}{l}14.8 \\
85.2\end{array}$ \\
\hline $\begin{array}{l}\text { Active third stage of labor } \\
\text { management }(n=554)\end{array}$ & $\begin{array}{l}\text { Yes } \\
\text { No }\end{array}$ & $\begin{array}{l}539 \\
15\end{array}$ & $\begin{array}{l}97.3 \\
2.7\end{array}$ \\
\hline $\begin{array}{l}\text { Prolonged third stage labor } \\
(n=554)\end{array}$ & $\begin{array}{l}\text { Yes } \\
\text { No }\end{array}$ & $\begin{array}{l}29 \\
525\end{array}$ & $\begin{array}{l}5.2 \\
94.8\end{array}$ \\
\hline Received blood after delivery & $\begin{array}{l}\text { Yes } \\
\text { No }\end{array}$ & $\begin{array}{l}43 \\
599\end{array}$ & $\begin{array}{l}6.7 \\
93.3\end{array}$ \\
\hline
\end{tabular}

Abbreviations: PPH, postpartum hemorrhage; CS, cesarean section. 


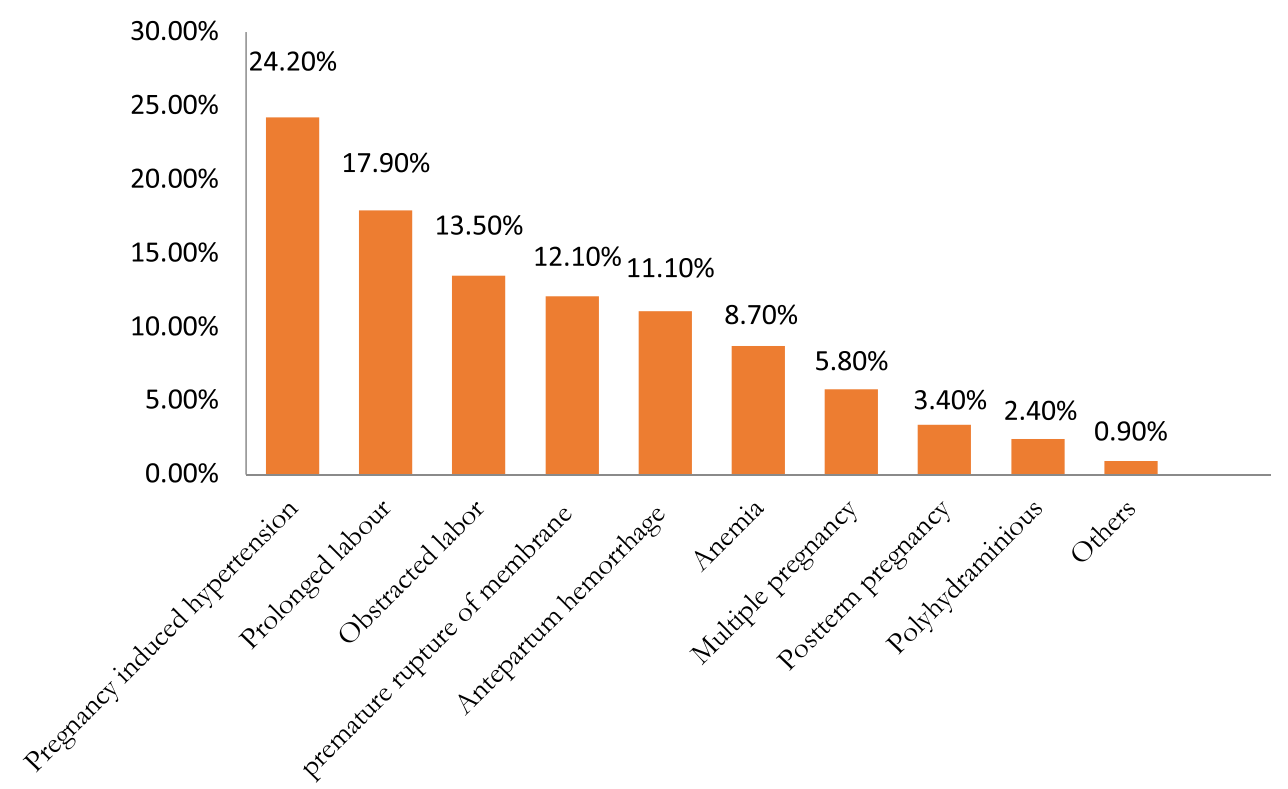

Figure I Distribution of complication in pregnancy and childbirth among mothers who gave birth at HFSUH, Eastern Ethiopia, $2020(\mathrm{n}=642)$.

and genital trauma (12\%) were the leading causes of PPH. History of PPH, ANC status, parity, and age were independently associated with $\mathrm{PPH}$. Women with history of $\mathrm{PPH}$ were 4.18 times $(\mathrm{aOR}=4.18 ; 95 \%$ CI $1.99,8.82)$ more likely to develop PPH as compared to women with no history of PPH. Women with no ANC follow up were 3.65 times $(\mathrm{aOR}=3.65 ; 95 \% \mathrm{CI} 1.97,6.76)$ more likely to develop PPH than their counterparts. The odds of having $\mathrm{PPH}$ was $3.33(\mathrm{aOR}=3.33$; 95\% CI $1.14,9.74)$ among grand multigravida women compared to primigravida. In addition, older women ( $>35$ years) were 3.08 times $(\mathrm{aOR}=3.08 ; 95 \%$ CI $1.56,6.07)$ more likely to develop PPH compared to women aged 20- to 34-years-old (Table 2).

\section{Discussion}

In this study, we assessed the magnitude of PPH and its associated factors among women who gave birth in a university hospital in eastern Ethiopia. We found that slightly more than one in ten women who gave birth in the hospital during the study period developed PPH. Women with history of PPH, >35-years-old, who did not attend $\mathrm{ANC}$, and grand multigravida were more likely to develop PPH.

Our finding is in line with findings reported in Sri Lanka (12.3\%) and Tanzania (11.9\%). ${ }^{17,23-26}$ But it is lower than findings from Southern Ethiopia (16.6\%), Pakistan (21.3\%), and Cameroon (23.6\%). ${ }^{12,17,23-26} \mathrm{In}$ addition, it is higher than findings from Dessie (5.8\%),
Debre Tabor (7.6\%), Bedele $(9.69 \%)$ in Ethiopia, Uganda $(9 \%)$ and Japan (8.7\%). ${ }^{10,11,13,17,26}$ Given that our study is conducted in a tertiary referral hospital where majority of women with complications are treated, our finding is expected to be higher. In addition, differences due to sample size, inclusion criteria or quality of documentation might be related to these differences. Moreover, magnitude of PPH may vary between and within geographical regions as a result of variation in diagnosis, quality of documentation or due to subjective estimation of blood loss). ${ }^{17,23-26}$

We found that women with history of $\mathrm{PPH}$ were more likely to experience PPH than their counterparts ${ }^{16}$ indicating the importance of counseling women about recurrence of PPH in subsequent pregnancies. Congruent with previous findings, $\mathrm{PPH}$ was more likely among women with no ANC follow up. ${ }^{10-13}$ Although not all risks of PPH could be identified during prenatal visits or predictable, ANC may serve as an opportunity to screen, diagnose and manage identified risk factors. Additionally, we found that PPH was more likely among older women, a finding also supported in previous studies from Senegal, Mali, the WHO multi country survey, Ethiopia (Bedele and Southern Ethiopia). ${ }^{10,12,27,28}$ As maternal age increases, pregnancy complications like uterine atony, gestational diabetes, pre-eclampsia, placenta previa, caesarean section, placental abruption which cause PPH also have a great chance to occur. ${ }^{28}$ Similarly, grand multigravida $(\geq 5)$ women were more likely to develop PPH in line with the finding from Cameroon. ${ }^{16,25}$ Repeated stretching of 
Table 2 Factors Associated with PPH Among Women Who Gave Birth in HFSUH, Eastern Ethiopia, 2020 (n =642)

\begin{tabular}{|c|c|c|c|c|c|}
\hline \multicolumn{2}{|l|}{ Variable } & \multicolumn{2}{|c|}{ PPH } & \multirow{3}{*}{$\begin{array}{l}\text { COR }(95 \% \mathrm{Cl}) \\
1.00 \\
1.74(1.09,2.77)\end{array}$} & \multirow{3}{*}{$\begin{array}{l}\text { aOR }(95 \% \mathrm{Cl}) \\
1.00 \\
0.95(0.52,1.74)\end{array}$} \\
\hline & & \multirow{2}{*}{$\begin{array}{l}\text { Yes (\%) } \\
37(10.2) \\
46(16.5)\end{array}$} & \multirow{2}{*}{$\begin{array}{l}\text { No (\%) } \\
326(89.8) \\
233(83.5)\end{array}$} & & \\
\hline Residence & $\begin{array}{l}\text { Urban } \\
\text { Rural }\end{array}$ & & & & \\
\hline History of PPH & $\begin{array}{l}\text { Yes } \\
\text { No }\end{array}$ & $\begin{array}{l}23(45.1) \\
60(10.2)\end{array}$ & $\begin{array}{l}28(54.9) \\
531(89.8)\end{array}$ & $\begin{array}{l}7.27(3.94,13.42) \\
1.00\end{array}$ & $\begin{array}{l}4.18(1.99,8.82) * * \\
1.00\end{array}$ \\
\hline ANC follow up & $\begin{array}{l}\text { Yes } \\
\text { No }\end{array}$ & $\begin{array}{l}41(8.3) \\
42(28.0)\end{array}$ & $\begin{array}{l}451(91.7) \\
108(72.0)\end{array}$ & $\begin{array}{l}1.00 \\
4.27(2.65,6.91)\end{array}$ & $\begin{array}{l}1.00 \\
3.65(1.97,6.76) * *\end{array}$ \\
\hline Gestational age & $\begin{array}{l}<37 \text { weeks } \\
37-4 \text { I weeks } \\
\geq 42 \text { weeks }\end{array}$ & $\begin{array}{l}3(7.5) \\
79(14.0) \\
I(2.6)\end{array}$ & $\begin{array}{l}37(92.5) \\
485(86.0) \\
37(97.4)\end{array}$ & $\begin{array}{l}0.49(0.15,1.65) \\
1.00 \\
0.17(0.22,1.23)\end{array}$ & $\begin{array}{l}0.77(0.21,2.89) \\
1.00 \\
0.22(0.28, I .68)\end{array}$ \\
\hline Complication & $\begin{array}{l}\text { Yes } \\
\text { No }\end{array}$ & $\begin{array}{l}22(10.6) \\
61(14.0)\end{array}$ & $\begin{array}{l}185(89.4) \\
374(86.0)\end{array}$ & $\begin{array}{l}0.73(0.43,1.22) \\
1.00\end{array}$ & $\begin{array}{l}0.69(0.37,1.29) \\
1.00\end{array}$ \\
\hline Age & $\begin{array}{l}<20 \text { years } \\
20-34 \text { years } \\
\geq 35 \text { years }\end{array}$ & $\begin{array}{l}\text { I }(1.1) \\
43(9.3) \\
39(42.9)\end{array}$ & $\begin{array}{l}87(98.9) \\
420(90.7) \\
52(57.1)\end{array}$ & $\begin{array}{l}0.112(0.015,0.83) \\
1.00 \\
7.33(4.35,12.32)\end{array}$ & $\begin{array}{l}0.19(0.23,1.72) \\
1.00 \\
3.08(1.56,6.07) * *\end{array}$ \\
\hline Duration of labor & $\begin{array}{l}\geq 24 \text { hour } \\
<24 \text { hour }\end{array}$ & $\begin{array}{l}9(23.1) \\
74(12.4)\end{array}$ & $\begin{array}{l}30(76.9) \\
523(87.6)\end{array}$ & $\begin{array}{l}2.12(0.97,4.64) \\
1.00\end{array}$ & $\begin{array}{l}2.22(0.78,6.34) \\
1.00\end{array}$ \\
\hline Gravidity & $\begin{array}{l}1 \\
2-4 \\
\geq 5\end{array}$ & $\begin{array}{l}6(3.6) \\
33(11.2) \\
44(28.2)\end{array}$ & $\begin{array}{l}185(96.4) \\
262(88.8) \\
112(71.8)\end{array}$ & $\begin{array}{l}1.00 \\
3.88(1.6,9.46) \\
12.1(5.001,29.3)\end{array}$ & $\begin{array}{l}1.00 \\
2.37(0.89,6.35) \\
\mathbf{3 . 3 3}(1.14,9.74) *\end{array}$ \\
\hline
\end{tabular}

Note: ${ }^{*}<<0.05 ; * * p=0.000$.

Abbreviations: $\mathrm{Cl}$, confidence interval; cOR, crude odds ratio; aOR, adjusted odds ratio.

muscle fibers may lead to loss of muscle tone that results in uterine atony which is the leading cause of $\mathrm{PPH} .^{29}$

The high burden of PPH in our study indicates the importance of auditing the appropriateness of obstetric management in HFSUH. ${ }^{30}$ Given that PPH management in the study hospital is found to be inadequate - weak vital sign monitoring, performing typing and cross-matching of blood, and fluid intake/output chart maintenance-interventions to prevent further complications and/or deaths from PPH should be instituted. With the already established effectiveness of tranexamic acid in the prevention of $\mathrm{PPH}^{31,32}$ or reducing the risk of deaths, ${ }^{33}$ it should be considered for use.

In conclusion, we found high proportion of women developing PPH compared to similar settings. We also found that PPH is more likely among women with prior history of PPH, $>35$-years-old, had no ANC, and grand multigravida. Screening history of PPH during ANC consultation or labor and delivery, and encouraging women to seek ANC is essential to identify women at risk of PPH to initiate close follow up and management. In addition to assessing burden of PPH (which was the primary objective of our study), a thorough of appropriateness and timeliness of management for patients is essential to avert the high maternal deaths attributed to PPH in the eastern Ethiopia and beyond.

\section{Authorship Contributions}

All authors contributed to data analysis, drafting or revising the article, have agreed on the journal to which the article will be submitted, gave final approval of the version to be published, and agree to be accountable for all aspects of the work.

\section{Acknowledgments}

We would like to thank Hiwot Fana Specialized University Hospital administrators for facilitation of the study. We are also grateful to the supervisors and data collectors for their support.

\section{Funding}

The work was funded by Haramaya University as part of a MSc study to SM. The organization has no role in the design, collection, analysis or interpretation of data or the decision to submit for publication. 


\section{Disclosure}

The authors report no conflicts of interest in this work.

\section{References}

1. WHO Guidelines Approved by the Guidelines Review Committee. WHO Recommendations for the Prevention and Treatment of Postpartum Haemorrhage. Geneva: World Health Organization; 2012.

2. Lalonde A, Daviss BA, Acosta A, Herschderfer K. Postpartum hemorrhage today: ICM/FIGO initiative 2004-2006. Int J Gynaecol Obstet. 2006;94(3):243-253. doi:10.1016/j.ijgo.2006.04.016

3. Weeks A. The prevention and treatment of postpartum haemorrhage: what do we know, and where do we go to next? BJOG. 2015;122 (2):202-210. doi:10.1111/1471-0528.13098

4. Ashigbie BP, Pharm B. Background Paper 6.16 Postpartum Haemorrhage; 2013.

5. Carroli G, Cuesta C, Abalos E, Gulmezoglu AM. Epidemiology of postpartum haemorrhage: a systematic review. Best Pract Res Clin Obstet Gynaecol. 2008;22(6):999-1012. doi:10.1016/j.bpobgyn.20 08.08.004

6. World Health Organization. Trends in maternal mortality 2000 to 2017: estimates by WHO, UNICEF; 2019.

7. Ethiopian Public Health Institute, (EPHI). Ethiopia mini demographic and health survey 2019: key Indicators; 2019.

8. Molla M, Mitiku I, Worku A, Yamin A. Impacts of maternal mortality on living children and families: a qualitative study from Butajira, Ethiopia. Reprod Health. 2015;12 Suppl 1(Suppl 1):S6. doi:10.1186/ 1742-4755-12-S1-S6

9. Tatek A, Bekana K, Amsalu F, Equlenet M, Rogers N. Prospective study on birth outcome and prevalence of postpartum morbidity among pregnant women who attended for antenatal Care in Gondar Town, north West Ethiopia. Androl Open Access. 2014;3(2):1-125.

10. Gudeta TA, Kebede DS, Nigeria GA, Dow MK, Hassen S. Magnitude of post-partum hemorrhage among women who received postpartum care at Bedele hospital south west, Ethiopia, 2018. J Preg Child Health. 2018;5(396):2.

11. Habitamu D, Goshu YA, Zeleke LB. The magnitude and associated factors of postpartum hemorrhage among mothers who delivered at Debre Tabor general hospital 2018. BMC Res Notes. 2019;12 (1):618-619. doi:10.1186/s13104-019-4646-9

12. Kebede BA, Abdo RA, Anshebo AA, Gebremariam BM. Prevalence and predictors of primary postpartum hemorrhage: an implication for designing effective intervention at selected hospitals, Southern Ethiopia. PLoS One. 2019;14(10):e0224579.

13. Temesgen MA. Magnitude of postpartum hemorrhage among women delivered at Dessie Referral Hospital, South Woll, Amhara Region, Ethiopia. J Womens Health Care. 2017;6(04):391. doi:10.4172/21670420.1000391

14. Geleto A, Chojenta C, Taddele T, Loxton D. Magnitude and determinants of obstetric case fatality rate among women with the direct causes of maternal deaths in Ethiopia: a national cross sectional study. BMC Pregnancy Childbirth. 2020;20(1):1-10. doi:10.1186/ s12884-020-2830-5

15. Combs CA, Murphy EL, Laros JRK. Factors associated with postpartum hemorrhage with vaginal birth. Obstet Gynecol. 1991;77 (1):69-76.

16. Stachetti T, Spodenkiewicz M, Winer A, Boukerrou M, Jesson J, Gérardin P. Factors associated with severe postpartum haemorrhage: systematic review using Bradford Hill's causality framework. $J$ Glob Health Rep. 2019;3:e2019085. doi:10.29392/joghr.3.e2019085

17. Fukami T, Koga H, Goto M, et al. Incidence and risk factors for postpartum hemorrhage among transvaginal deliveries at a tertiary perinatal medical facility in Japan. PLoS One. 2019;14(1):e0208873. doi:10.1371/journal.pone.0208873
18. Anderson JM, Etches D. Prevention and management of postpartum hemorrhage. Am Fam Physician. 2007;75(6):875-882.

19. Maswime S, Buchmann E. A systematic review of maternal near miss and mortality due to postpartum hemorrhage. Int J Gynaecol Obstet. 2017;137(1):1-7. doi:10.1002/ijgo.12096

20. Maswime TS, Buchmann E. Near-miss maternal morbidity from severe haemorrhage at caesarean section: a process and structure audit of system deficiencies in South Africa. S Afr Med J. 2017;107 (11):1005-1009. doi:10.7196/SAMJ.2017.v107i11.12340

21. Kumar N. Postpartum hemorrhage; a major killer of woman: review of current scenario. Obstet Gynecol Int J. 2016;4(4):00116. doi:10.15406/ogij.2016.04.00116

22. World Medical Association. World Medical Association Declaration of Helsinki: ethical principles for medical research involving human subjects. JAMA. 2013;310(20):2191-2194. doi:10.1001/jama.20 13.281053

23. Gani N, Ali TS. Prevalence and factors associated with maternal postpartum haemorrhage in Khyber Agency, Pakistan. J Ayub Med Coll. 2013;25(1-2):81.

24. Goonewardene M, Silva C, Medawala M, Karunarathna S. The occurrence, management and outcomes of post partum haemorrhage in a teaching hospital in Sri Lanka. Sri Lanka J Obstet Gynaecol. 2013;34(4):4. doi:10.4038/sljog.v34i4.5931

25. Halle-Ekane GE, Emade FK, Bechem NN, et al. Prevalence and risk factors of primary postpartum hemorrhage after vaginal deliveries in the Bonassama District Hospital, Cameroon. Int J Trop Dis Health. $2015 ; 1-12$.

26. Ononge S, Mirembe F, Wandabwa J, Campbell OM. Incidence and risk factors for postpartum hemorrhage in Uganda. Reprod Health. 2016;13(1):1-7. doi:10.1186/s12978-016-0154-8

27. Tort J, Rozenberg P, Traoré M, Fournier P, Dumont A. Factors associated with postpartum hemorrhage maternal death in referral hospitals in Senegal and Mali: a cross-sectional epidemiological survey. BMC Pregnancy Childbirth. 2015;15(1):1-9. doi:10.1186/ s12884-015-0669-y

28. Sheldon W, Blum J, Vogel JP, et al. Postpartum haemorrhage management, risks, and maternal outcomes: findings from the World Health Organization multicountry survey on maternal and newborn health. BJOG. 2014;121:5-13. doi:10.1111/1471-0528.12636

29. Vlassoff M, Abdalla AH, Gor V. The Cost to the Health System of Postpartum Hemorrhage in Egypt. USA: Guttmacher Institute; 2016.

30. Tura AK, Aboul-Ela Y, Fage SG, et al. Introduction of criterion-based audit of postpartum hemorrhage in a university hospital in eastern ethiopia: implementation and considerations. Int $J$ Environ Res Public Health. 2020;17(24):E9281. doi:10.3390/ijerph17249281

31. Saccone G, Della Corte L, D'Alessandro P, et al. Prophylactic use of tranexamic acid after vaginal delivery reduces the risk of primary postpartum hemorrhage. J Matern Fetal Neonatal Med. 2020;33 (19):3368-3376. doi:10.1080/14767058.2019.1571576

32. Della Corte L, Saccone G, Locci M, et al. Tranexamic acid for treatment of primary postpartum hemorrhage after vaginal delivery: a systematic review and meta-analysis of randomized controlled trials. J Matern Fetal Neonatal Med. 2020;33(5):869-874. doi:10.1080/14767058.2018.1500544

33. WOMAN Trial Collaborators. Effect of early tranexamic acid administration on mortality, hysterectomy, and other morbidities in women with post-partum haemorrhage (WOMAN): an international, randomised, double-blind, placebo-controlled trial. Lancet. 2017;389 (10084):2105-2116. doi:10.1016/S0140-6736(17)30638-4 


\section{Publish your work in this journal}

The International Journal of Women's Health is an international, peerreviewed open-access journal publishing original research, reports, editorials, reviews and commentaries on all aspects of women's healthcare including gynecology, obstetrics, and breast cancer. The manuscript management system is completely online and includes a very quick and fair peer-review system, which is all easy to use. Visit http://www.dovepress.com/testimonials.php to read real quotes from published authors. 